\title{
Inequality, redistribution, and economic growth
}

\section{Working Paper}

Author(s):

Zweimüller, Josef

Publication date:

2000

Permanent link:

https://doi.org/10.3929/ethz-a-004373019

Rights / license:

In Copyright - Non-Commercial Use Permitted

Originally published in:

Working paper / Institute for Empirical Research in Economics 31 


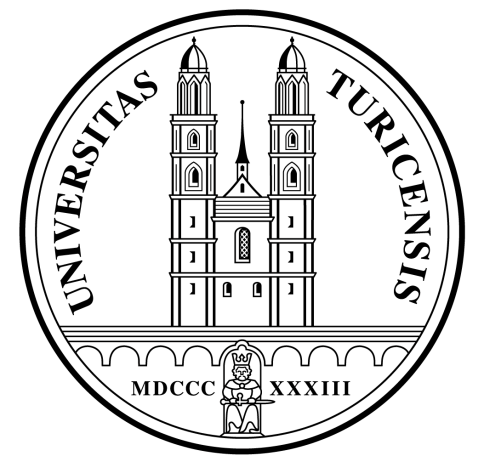

Institute for Empirical Research in Economics

University of Zurich

Working Paper Series

ISSN 1424-0459

Forthcoming in: Empirica (2000) Vol. 27, pp. 1-20

Working Paper No. 31
INEQUALITY, REDISTRIBUTION, AND ECONOMIC
GROWTH

Josef Zweimüller

January 2000 


\title{
INEQUALITY, REDISTRIBUTION, AND ECONOMIC GROWTH ${ }^{*}$
}

\author{
Keynote Speech \\ Annual Meeting of the Austrian Economic Association 1999 \\ University of Linz
}

JOSEF ZWEIMÜLLER

Universität Zürich, CEPR and IZA

September 1999

\begin{abstract}
This paper provides a critical review of the recent literature on inequality and growth. After discussing historical and more recent distributional trends as well as empirical evidence on the relationship between inequality and growth, I focus on recent explanations of the inequality-growth puzzle. I consider both the impact of the functional and the personal distribution on long-run growth rates. A final section discusses a rather neglected issue in the recent literature: the impact of expected demand for innovation decisions.
\end{abstract}

Keywords: Income Distribution, Labor Share, Endogenous Growth, Demand Composition.

JEL: $\quad$ D63, D9, E21, E22, E25, O15, O31. 


\section{Introduction}

The goal of a 'just' distribution of income and wealth is a central issue in the economic policy debates of modern industrialized countries. An open question, however, is not only what is meant by a just distribution, but also what is the impact of inequality on the aggregate outcomes of an economy. Clearly, one of the most important potential effects of inequality is its impact on the incentives to save and invest. The possible effects of inequality on economic growth due to such incentives is the topic of the present paper.

Is there a trade-off or a complementarity between equity and efficiency? Economists' opinion on this topic is far from uniform. One position holds that a just distribution is a necessary condition for a prosperous economic development. Adam Smith turns out to be a prominent advocate of this view. In the 'Wealth of Nations' he writes

"No society can surely be flourishing and happy of which the far greater part of the members is poor and miserable."

For this view a high income level for few individuals or privileged ranks cannot be a source of development and growth. Societies' goal should be to raise the standard of living of the whole population including the lower classes, this in turn being the basis of a prosperous economy.

Mainstream economics of the past decades takes a somewhat different position. The opinion is that well functioning markets can guarantee efficiency, but the outcome may not necessarily be a just one. In the words of Arthur Okun:

"The trade-off between equity and efficiency is our biggest socio-economic trade-off, We can't have our cake of market efficiency and share it equally."

Throughout the post-war period until recently this position was accepted by the majority of economists. According to this position, economic progress will trickle down to the poor if the wealthy are unimpeded to pursue their goals. The logic of this equity-efficiency trade-off implies that policy makers have the choice between higher living standards on average but high inequality, or a smaller pie but a larger slice for the poor. In other words, more justice in the distribution of income requires to sacrifice output. The price of redistributing income is a lower output, or in a dynamic setting, slower long-run growth. 
This opinion is not undisputed in the recent literature. While this new literature does not deny that there is some truth in the above arguments, the efficiency-equality tradeoff as a valid generalization has been questioned. This challenge of the recent literature is based both on empirical and theoretical developments.

First, the tradeoff has been questioned as a matter of fact. There is very little empirical evidence suggesting that initial inequality in the distribution of income and wealth has a positive impact on subsequent long-run growth rates. To the contrary, studies that regress long-run growth rates on inequality indicators using cross-country data find a negative correlation between these two variables. It seems that, if there is a relationship at all, inequality is harmful for growth.

The second reason that casts doubt on the equity-efficiency tradeoff comes from the theoretical literature. More and more economists are arguing that inequality itself may have negative incentive effects. High inequality may lead to lower levels of work effort and, what is of crucial importance in a growth context, to restricted incentives and/or opportunities to undertake productive investments in education and innovative activities. This is not to say that the conventional analysis has become theoretically less compelling or even redundant. However, the previously one-sided focus on the negative side of equality and redistribution has been complemented by a more comprehensive view of the incentive problems facing modern economies.

The object of the present paper is to give a critical review of the recent literature on the inequalitygrowth puzzle. The aim is not to give a comprehensive survey of this literature, but to outline the most important ideas as well as those approaches which have received too little attention in the recent debate. ${ }^{1}$ I will touch both some empirical points as well as the recent discussion of the inequality-growth puzzle in the theoretical literature.

The paper is organized as follows. I will start with a review of some empirical facts in Section 2. There I will first display some historical trends in the evolution of the income distribution and then discuss some more recent trends. I will then briefly review the literature on the empirical relationship between inequality and long-run growth rates.

In Section 3 I will consider the role of the functional distribution of income in the growth process from a theoretical point of view. While the functional distribution plays a central role in classical 
and Keynesian theories of economic growth, recent theories devote only little attention to it. In my opinion, this is not justified both on empirical and theoretical grounds.

In Section 4 I will discuss the role of the personal distribution for the long-run growth experience of economies. It is predominantly the personal distribution which has attracted much attention in the recent literature. I will confine the discussion to the main approaches, in particular to the consequences of imperfect capital markets.

Section 5 presents an approach that has attracted far less attention in the recent literature but is central to Keynesian theories of investment and growth: the role of demand. In almost all recent approaches, the demand for produced output plays a passive role in determining the rate of technical progress. While this may be a convenient simplification for many purposes, it leaves one crucial aspect out of consideration: the role of expected demand and expected profits for investment and innovation decisions. In Section 5 I will sketch a model in which the income distribution plays a central role as a determinant of expected demand.

Section 6 summarizes and draws some conclusions.

\section{Empirical Evidence: Trends in Income Distribution and the Relationship between Inequality and Growth}

\subsection{Changes in the Evolution of Income Inequality}

Let us first take a look at the empirical evidence on long-run distributional trends of various industrialized countries. ${ }^{2}$ Until two or three decades ago, the 'Kuznets-curve' was accepted as an empirical stylized fact. The Kuznets-curve (Kuznets, 1955) describes the relationship between income inequality on the one hand, and the level of economic development, i.e. per-capita income, on the other. According to the Kuznets-hypothesis, economic progress, as measured by per capita income, is initially accompanied by rising inequality but as the benefits of development trickle down to the more backward sectors and regions in the economy these disparities start to decrease. This implies a hump-shaped relationship between income inequality and per-capita income. Inequality increases when per-capita income is low and starts to decrease after a certain threshold has been surpassed. 
Figure 1 depicts the downward sloping branch of the Kuznets-curve for various industrialized countries. As a measure of inequality the vertical axis shows the income of the 20 per cent richest as a fraction of GDP. The horizontal axis measures the level of the per-capita income (on a logarithmic scale). The lines in the figure measure the changes in these two variables for various countries since the end of last century. Consider, for example, the development in the U.K. In 1880 the U.K. had a per-capita income of less than 2,000 \$ (in 1970 prices) while roughly $60 \%$ of the total income was earned by the 20 per cent richest. A century later, incomes have increased to more than 7,000 \$, and the fraction of total income earned by the 20 per cent richest has decreased to less than 40 per cent. Similar trends can be seen for most of the other countries shown in Figure 1: an increase in per capita income goes hand in hand with a reduction of income inequality. This trend is visible until the mid 1970s.

\section{Figure 2: Recent Trends in Income Inequality}

Since the late 1970s, however, the picture has changed. Figure 2 shows the evolution of the income distribution for the G7 industrialized countries since the base year 1977. The horizontal axis measures time while the vertical axis measures inequality with an index $(1977=100)$ for the relative deviation of the Gini-index from its 1977-value. It is well known, that there has been a dramatic increase in inequality in the U.K.. In other countries, such as Germany, the U.S. and Japan there was a slight increase in inequality since 1977. In contrast, in France, Canada and Italy there was either no change or there was a reduction in inequality.

Figure 2 shows that the income inequality in these countries is by no means a constant. It also shows that there is no universal trend towards more inequality as is frequently claimed. There is significant variation across countries. ${ }^{3}$

The above data refer to the personal distribution of income. It is no less interesting to look at the functional distribution. In macroeconomic contexts, income distribution is frequently defined as the distribution of income between factors of production, that is the shares in national income of labor and non-labor incomes, or 'factor shares'. Referring to Kaldor's stylized facts on the growth process, it is often implicitly assumed that the functional distribution of income is a very stable variable which fluctuates around a horizontal trend. 
Figure 3 displays the time-series data of the labor share of GDP in various countries since the early 1960s. It is evident from the figure that these series show substantial fluctuations. ${ }^{4}$ The assumption that the labor share is constant over time appears to be consistent with the data for the U.K.. The evidence is less clear for the U.S. where the labor share has decreased somewhat in the past decades. In Germany and France the labor share was rising until the early 1980s but shows a significant reduction thereafter. In sum, Figure 3 shows that the functional income distribution displays substantial fluctuations over time. The assumption that the labor share is a constant is hard to justify.

\subsection{Income Inequality and Economic Growth}

Let us now turn to the central topic of this paper and consider the evidence on the relationship between income inequality and economic growth.

\section{Figure 4: Inequality and Growth}

Figure 4 plots a measure of the long-run growth rate (over the period 1970-1988) against a measure of the Gini-coefficient. ${ }^{5}$ This figure which is taken from a paper by Clarke (1995) shows a clear result: more inequality is associated with lower long-run growth rates. The results are representative for numerous other studies and do not depend on the particular time period nor on a particular inequality indicator used in the empirical analysis.

The above findings are a major development in the new empirical literature on inequality and growth. This literature started with a paper by Berg and Sachs (1987) which did not analyze the determinants of long-run growth rates, but the structural causes of the debt crises in the 1980s. Surprisingly, these authors found that income inequality was one of the most important factors in explaining the probability of debt rescheduling in a cross-section of middle-income countries. Countries with very high inequality such as Brazil, the Philippines or Morocco had to reschedule their debt on an emergency basis, while other countries with a similar level of development but lower inequality, like Thailand, India or Tunisia could repay their debt. Evidently, the ability to repay depends closely on the savings formation in the economy. It seems that savings formation was higher in economies with a relatively more even income distribution. 
The empirical relationship between long-run growth and income inequality was analyzed not until later. "Is inequality harmful for growth?" is the title of a paper by Persson und Tabellini (1994). The answer of the authors as well as of Alesina und Rodrik (1994) is "yes". Using cross-country data and historical time-series, these studies show that higher inequality at the beginning of a longer-term period has a negative impact on the growth rate during the subsequent period. The authors interpret this as a causal effect of inequality on the long-run growth prospect of an economy.

Deininger and Squire (1998) from the World Bank replicated these studies with more recent and internationally comparable data. They find that the impact of initial inequality on subsequent growth is negative in most cases but not always significant. However, inequality in the distribution of assets, as proxied by the distribution of land, has a significant and robust negative effect on subsequent growth. ${ }^{6}$

\section{The Functional Distribution of Income and Economic Growth}

The empirical evidence from cross-country regressions suggests that income inequality is by no means a necessary condition for favorable growth prospects of an economy. If such a relationship exists at all, then the opposite is true: inequality is harmful for growth.

The above findings are in sharp contrast to the prejudice of most economists which is based on the assumption that the savings rate of the rich is higher than the savings rate of the poor. This argument goes back to the classical economists, according to whom the dynamics of accumulation in an economy is driven by the capital owners. The argument is also central in Keynesian theories of growth and income distribution, in which the savings rate from profits is higher than the savings rate from wages (Kaldor, 1956). When economic growth depends on the aggregate savings rate, it follows that a high profit share is good for growth.

This leads us to the role of the functional income distribution, i.e. the distribution of income between wages and profits. We have seen above that the labor share is far from stable over time. From an empirical point of view, it is therefore suggestive to look at the role of factor shares in the standard macroeconomic models. I will do that in the context of the simplest endogenous growth model, an AK-model. 
In the AK-model, aggregate output $Y(t)$ is proportional to the aggregate capital stock $K(t)$, the production function can therefore be written as

(1) $\quad Y(t)=A(L) \cdot K(t)$

The parameter $A$ reflects the technological structure of production in the economy. $A$ may depend on the size of the labor force $L$ which is assumed to be constant over time. For the purpose of the present argument, however, the only important point is that $A$ measures the efficiency with which the capital stock is used in production.

Clearly, the above production function has increasing returns to scale if labor has a productive role. This means that a competitive allocation of output is infeasible: factors cannot be rewarded their marginal product. At this stage we will simply assume that the market structure and the institutions are such that a share $\lambda$ accrues to labor, and the complementary share $1-\lambda$ accrues to capital. In a more elaborated model $\lambda$ would be a function of the market structure as well as market imperfections that affect the demand for and the prices of production factors.

With these assumptions on the functional distribution, labor and capital income can be expressed as:

$$
w(t) L=\lambda \cdot Y(t) \quad \text { and } \quad r K(t)=(1-\lambda) \cdot Y(t)
$$

where $w(t)$ is the wage rate and $r$ is the interest rate. Note that in equation (2) the interest rate is independent of $t$. Using equation (1) it is easy to see that this is actually the case:

$$
r=(1-\lambda) \cdot \frac{Y(t)}{K(t)}=(1-\lambda) \cdot A
$$

Thus the interest rate is constant over time and decreases with the labor share.

Now we can consider the impact of the labor share $\lambda$ on the economy's growth rate. I will do that for the two 'workhorse' models of growth theory: the Ramsey-model and the overlapping generations-model. ${ }^{7}$ 
Consider first the Ramsey-model. In this-model, the household maximizes utility over an infinite time horizon and for the purpose of the present analysis we assume that lifetime utility takes the form

$$
U={ }_{\tau=0}^{\infty} \frac{c(\tau)^{1-\sigma}-1}{1-\sigma} \cdot\left(\frac{1}{1+\rho}\right)^{\tau}
$$

where $U$ is the present value of lifetime utility, $c(\tau)$ is the level of consumption in period $\tau, \rho$ is the rate of time preference and $\sigma$ is the inverse of the intertemporal elasticity of substitution. The functional form in (4) together with a constant interest rate guarantees that the optimal growth rate of consumption is constant. Moreover, in a balanced growth equilibrium output and consumption grow at the same rate. The growth factor is given by the familiar relation which expresses the change in consumption and output as a function of the interest rate $r$, the rate of time preference $\rho$ and the intertemporal elasticity of substitution in consumption $1 / \sigma$.

$$
\frac{Y(t+1)}{Y(t)}=\frac{C(t+1)}{C(t)}=\left(\frac{1+r}{1+\rho}\right)^{1 / \sigma}=\left(\frac{1+(1-\lambda) A}{1+\rho}\right)^{1 / \sigma} .
$$

The last expression in equation (5) is obtained by replacing the interest rate by the right-hand-side of equation (3) so that the growth factor can be expressed in terms of the labor share $\lambda$. Clearly, an increase in this share leads to a lower interest rate and reduces the incentive to save. The result is slower growth.

The result of equation (5) is perfectly compatible with the conventional approach to the impact of the labor share on the growth rate. If the income flow of the rich is predominantly capital income and the income flow of the poor predominantly wage income, than the rich have a higher savings rate than the poor. An increase in the labor share decreases the growth rate, since there is redistribution from households with a high savings rate to those with a low savings rate. The consequence is a negative relation between inequality and growth.

Bertola (1993) has shown that the conventional Keynesian approach and the AK/Ramsey-model show a striking similarity with respect to savings behavior. The steady-state equilibrium in the AKRamsey model is characterized by a situation in which the propensity to consume form wages is unity while an (endogenous) fraction of capital income is saved. Just like in the Keynesian analysis 
an increase in the labor share redistributes income away from the factor that contributes disproportionately to aggregate savings.

An immediate implication of this simple model is that taxation of capital income is detrimental to growth. Taxes on capital reduce the after-tax interest rate and therefore the incentive to save. The consequence is a lower growth rate.

We reach a very different conclusion when we consider Diamond's (1965) overlapping generation model. In this model, individuals live for two periods, in the first period they work, in the second they retire. Ruling out bequests, the objective function of a typical household is the same as in equation (4) above. The 'sole' difference is that only today's and tomorrow's utility enter the decision problem. In other words, the upper limit of summation in equation (4) is 1 instead of $\infty$. In the first period individuals get wage income $w(t) L$, part of which is consumed and part of which is saved for retirement. In the second period these savings plus the accrued interest income is consumed.

How is the growth rate determined in such a set-up? Since there are no bequests, today's savings of the young represent tomorrow's capital stock. That is, we have

$$
\frac{Y(t+1)}{Y(t)}=\frac{S(t)}{K(t)}=\frac{w(t) \cdot L}{K(t)} \cdot s(\lambda)=\lambda \cdot A \cdot s(\lambda),
$$

where $s$ is the savings rate. In general, $s$ depends on the interest rate and therefore on the labor share $\lambda$.

We can now ask, how a change in the labor share affects growth in the context of the overlapping generations model. The answer is not a priori clear. On the one hand, a higher labor share increases the wage bill in the economy, that is the income of the young. Since only the young save, an increase in $\lambda$ leads to higher savings and therefore to a higher future capital stock. This direct effect of the labor share tends to increase the growth rate.

On the other hand, an increase in the labor share leads to a lower interest rate and, for this reason has an indirect impact on the savings rate. It is easy to show that the impact of the interest rate on the savings rate depends on the intertemporal elasticity of substitution in consumption, that is on the parameter $\sigma$. When $\sigma=1$, that is when the utility function is logarithmic, the savings rate is 
independent of the interest rate; in this case income and substitution effects are of equal magnitude. If $\sigma>1$, the savings rate decreases if the interest rate increases. If $\sigma<1$, the two variables move in the same direction.

A variety of empirical studies has shown that the intertemporal elasticity of substitution in consumption, $1 / \sigma$, is relatively small and in most estimates considerably lower than unity. This suggests that we have $\sigma>1$. In this case an increase in the labor share $\lambda$ (which decreases the interest rate) leads to an increase in the savings rate. In sum, in the empirically more plausible case $\sigma>1$, both above effects of an increased labor share on growth move in the same direction. The result is that an increase in the labor share leads to an unambiguous increase in the growth rate.

An immediate implication of these arguments is that the taxation of capital income can lead to higher growth. If this is true, then we should observe high savings rates in periods when capital taxes are high and vice versa. Figure 5 gives a tentative answer to this question. This figure shows time series data on both the savings rate (the bold line) and tax rates on capital income (the thin line) since the mid 1960s for the U.S.. Interestingly, savings rates and capital taxes show a highly positive correlation over time. This evidence is certainly consistent with the result of the overlapping generations model.

Figure 5: Capital Taxation and Aggregate Savings, U.S. 1965-1990

We have seen that the results of the two standard models of macroeconomics lead to fundamentally different conclusions concerning the impact of the labor share on growth. Which conclusions should we draw from this analysis?

In my opinion, a first conclusion is that the conventional wisdom should be viewed somewhat more sceptical. Neither from a theoretical nor from an empirical point of view can strong conclusions be drawn on the impact of capital taxation on growth. A second conclusion is that more effort should be devoted to provide more reliable empirical evidence on the impact of changes in the labor share on long-run growth rates. Finally, the above arguments make it clear that the appropriate model framework is essential when it comes to judging the role of the functional income distribution for the long-run growth process. 


\section{Long-run Growth and the Personal Distribution of Income and Wealth}

Let us now take a look at the role of the personal distribution of income and wealth in the growth process. As mentioned in the beginning, recent theoretical and empirical literature on the relationship between income inequality and economic growth is primarily occupied with the role of the personal distribution. Persson and Tabellini (1994), who were the first to point to a possible negative inequality-growth relationship, suggest the following explanation. High inequality in pretax incomes leads the majority of people to vote for redistribution. The consequence is a progressive tax system. Inequality is bad for growth, because inequality induces redistribution and the distortions resulting from this redistribution are detrimental to incentives to undertake productive investments.

The available empirical evidence, however, does not support the above model. ${ }^{8}$ First, in a crosssection of countries, there is no statistically significant impact of inequality on taxes and transfers. Secondly, there is very little evidence that redistribution has a detrimental impact on investment and growth. Whether or not higher taxes have an impact on growth and investment depends on how the tax revenues are spent: The transfer/GDP ratio and the fraction of public expenditures on education frequently have a positive and statistically significant impact on growth.

There are further plausible reasons for a negative inequality-growth relationship for which empirical evidence exists. One such explanation is that inequality, if not mitigated by public redistribution measures, leads to political instability which has a negative impact on the economy's growth rate. ${ }^{9}$ The more recent literature goes a step further and asks how social capital, trust and the degree of acceptance of social norms can promote economic growth. ${ }^{10}$ It is evident that for an explanation of the determinants of these factors, the distribution of income and wealth has an important role to play.

However, the predominant explanation put forward in the recent literature is neither based on politico-economic nor on sociological explanations. This approach is based on the argument that imperfect capital markets are the source of possible inefficiencies of excessive inequality. ${ }^{11}$ For evident reasons, the accumulation of human capital plays a central role in modern growth theory. Education not only has direct costs but usually implies an initial period without income. An individual who has not inherited the necessary funds and cannot raise these funds on the capital market has no access to the education system. This will lead to an inefficient allocation of resources, if the inherited wealth does not coincide with the innate abilities. In that case, 
individuals with high potential returns to education cannot acquire the necessary human capital while other individuals with lower innate abilities may be able to incur the education costs.

\section{Figure 6: Investment in Human Capital with Perfect Capital Markets}

The crucial point can be made by looking at Figure 6. On the horizontal axis, we measure the level of human capital investment of a certain individual. The vertical axis shows the output level resulting from this investment. Let us further assume for simplicity, that the relationship between investment and output is the same for all individuals. Since human capital is the accumulated factor this means that all individuals are of equal ability.

Figure 6 shows the equilibrium that will arise if capital markets are perfect. In this case there is a unique interest rate at which individuals can borrow and lend. The optimal investment level is where the marginal return equals the interest rate. In Figure 6 this condition is satisfied at an investment level $H^{*}$ which leads to output $Y^{*}$ in the next period. Individuals who have large inheritances, can lend their remaining wealth. Individuals, who have inherited too little or nothing at all can realize investment $H^{*}$ by borrowing the corresponding funds at the prevailing interest rate. The per-capita income of the next period is therefore independent of the wealth distribution and given by $Y^{*}$.

\section{Figure 7: Imperfect Capital Markets}

With imperfect capital markets, the situation is different. This can be demonstrated most easily by looking at the extreme case - that is the complete absence of capital markets. In this case the investment possibilities are given by the inherited wealth. The rich can invest a lot, $H_{R}$ in Figure 7 , whereas the poor can invest only little, $H_{A}$. If the marginal returns are decreasing in the level of investment the wealth distribution affects the equilibrium outcome. The per-capita income of next period - the average of $Y_{R}$ and $Y_{A}$ in Figure 7 - is lower, the more unequal the wealth distribution is. This result follows immediately from the concavity of the investment-output relationship.

These simple diagrams summarize what is behind most explanations of the inequality-growth relationship that rely on imperfect capital markets: heterogeneous returns to investment. Redistribution leads to higher incomes, because it improves the investment opportunities of individuals with high marginal returns to investment. If such redistribution is at the expense of 
individuals with low returns, the aggregate productivity of investment and therefore average incomes in the whole economy increase.

In the above example, self-financing constraints lead to a situation where the returns to investment are not equated at the margin between the poor and the rich. Aghion und Howitt (1998) show that this result is more general and does not depend on the specific form of the imperfection on the capital market.

From an empirical point of view, imperfect capital markets are certainly an important candidate to explain the inequality-growth puzzle. For instance, most studies show that there is a strong negative correlation between income inequality and the secondary school enrollment rates. This relationship does not only hold for developing countries, but is also true for the rich economies. Direct tests of this approach, however, are difficult to undertake due to the lack of appropriate aggregate indicators of capital market imperfections. A high research potential lies in a more disaggregate analysis of the causes and consequence of liquidity constraints for the acquisition of human capital and other investment decisions. ${ }^{12}$

\section{Inequality, Demand Composition and Innovations}

In the above models, the distribution of income and wealth affects the returns to accumulation and has therefore a direct impact on the supply of tomorrow's factors of production. The demand for produced output plays a passive role and has no impact on the incentives to undertake productive investments. While this is a convenient simplifying assumption for many purposes it leaves other potentially important mechanisms out of consideration. Few economists would contradict the proposition that the expected level of demand for produced output is an important determinant of investment and innovation decisions. Income inequality comes into play, when rich and poor consumers buy different goods in different amounts so that the expected level of demand depends on the income distribution.

To illustrate the demand-side mechanisms that could contribute to an explanation of the inequalitygrowth relationship, I will now sketch an own model (Zweimüller, 1999). ${ }^{13}$ In this model, income inequality plays a role because it shapes both the level and the time path of demand for an innovator's product. If innovations are the driving force behind economic growth, then the 
expected level of demand for innovative products becomes an important determinant of the aggregate dynamics of an economy.

Let us assume that consumers have a hierarchic structure of preferences so that they first concentrate their consumption expenditures on basic goods, before they start to buy conveniences and luxury goods. Let us consider the decision problem of a potential innovator under these circumstances. A firm that wants to introduce a new product on the market, will initially have only rich buyers, the poor cannot afford a new good. This leads to the presumption that a class of very rich people that generates the necessary demand is a necessary determinant for a dynamic and innovative economy. The idea that the consumption of luxury goods is an important engine of growth creating new wants and maintaining the incentives to provide effort, is an argument which has already be stressed by the classical economists.

\section{Figure 8: Income Inequality and the Dynamics of Demand}

Is inequality therefore good for growth because it induces innovations? The answer is: it can, but it need not be. Figure 8 shows the evolution of demand for an innovator's product over time. Initially demand is low, only the rich are willing to pay for the new product, whereas poorer individuals cannot afford the new good. As time goes by, demand grows as less wealthy individuals become willing to pay for this good. Clearly, the time path of demand depends on the distribution of income. If incomes are very evenly distributed, then demand may initially be low, but it will grow very quickly - this is the case for the dotted line in Figure 8. With a very unequal distribution, demand may initially be high but the market grows only slowly - this scenario is shown by the solid line in Figure 8.

\section{Figure 9: Income Distribution and the Composition of Demand}

Figure 9 shows the distribution of consumption across all households in the economy. On the horizontal axis, I measure an index for the priority in consumption of a certain good. Goods with a very low value of this index are basic goods that are consumed by all households, whereas goods with a high index are more luxurious goods. Let us assume that each household consumes only one unit from each good. Then the level of consumption of a household is given by the number of goods a household can afford. The area B in Figure 9 shows that fraction of consumers than cannot afford $\operatorname{good} N$, whereas the area $A$ measures the fraction of consumers that can afford $\operatorname{good} N$. 
If we assume in addition that the prices of all goods are equal, then the distribution depicted in Figure 9 is equal to the distribution of consumption expenditures. And if we further assume that all households have the same savings rate, this distribution also reflects the distribution of income in the economy.

Now let us assume that at a certain point of time $N$ goods have been invented. The poorest consumers cannot buy all $N$ goods, but can afford only the first $C_{A}$ goods. The richest consumers would like to buy $C_{R}$ goods, that is, they would like to buy more goods than are available on the market. If the next innovator comes along with a slightly more luxurious product than good $N$, the area $A$ measures the fraction of consumers who want to buy this good from the period when it is introduced.

Of course, area $A$ is also a measure of demand that cannot be realized, since the goods more luxurious than $N$ have not yet been invented. We could imagine that the purchasing power reflected in area $A$ is directed towards luxuries that need not be invented (like gold and diamonds) or that the rich can reduce their labor supply.

How does demand and therefore income inequality affect the incentive to innovate. To get the intuition right, we have to be aware that Figure 9 shows the distribution of income (and consumption) at a given point of time. Over time, new innovations take place, these innovations induce technical progress, and the income of all consumers in the economy will rise. This means, that over time the distribution in Figure 9 shifts to the right.

Now consider the decision of an innovator. With a given cost to introduce a new product, with given profits per unit of sold output and with a given interest rate, the value of an innovation is determined by the time path of demand. Clearly, under our assumptions the time path of demand is directly determined by the income distribution. To see this more clearly, consider the situation of the most recent innovator, the firm that produces $\operatorname{good} N$. The position of this particular good in the preference hierarchy remains unchanged over time, but the distribution shifts to the right since incomes and consumption expenditures are growing. This means that - for this particular good - the area $A$ becomes larger over time, meaning that the fraction of consumers that can afford good $N$ grows over time an sooner or later, even the poorest households will be able to afford good $N$. Clearly, the shape of the income distribution affects the time path of an innovator's demand. 
The interesting question is, what happens when there is a redistribution of income? The answer to this question depends on how the various consumers are affected and how such a redistribution affects the actual and the future demand of an innovator. If there is redistribution among the fraction of consumers that can afford all $N$ goods, that is within the area A, there is no impact on the innovator's demand. Such a redistribution affects only households that can afford a new good anyway. The level and the time path of demand of the innovator remain unchanged. And therefore such a redistribution has no impact on innovations and growth.

However, if income is redistributed from very rich to very poor consumers, it has an impact on the innovator's demand. Consider a mean-preserving redistribution that leaves the size of areas $A$ and $B$ unchanged but reduces the upper and increases the lower limit of the distribution, that is a redistribution from the very rich to the very poor. Such a redistribution is favorable from the point of view of an innovator. The reason is that the reduction in the incomes of the very rich has no impact on the innovator's demand: these consumers will still buy good $N$ after the redistribution. However, the poorer consumers will become relatively richer and will buy the innovator's good sooner. In other words, such a redistribution shifts the innovator's future demand closer towards the present. This increases the value of an innovation.

Things are different if there is a redistribution from relatively rich to poor households within the area $B$. In this case, the time path of the innovator's demand is affected twofold. On the one hand, demand of the relatively rich consumers is shifted towards later periods. On the other hand, the poor consumers will become richer and will be able to afford the innovator's earlier. The net effect of such a redistribution is always negative for the innovator. As a consequence of discounting it is better to have a smaller profit flow in the near future, as opposed to a larger profit flow later on. The consequences are lower discounted profits of an innovation and therefore lower growth.

The relationship between the composition of demand and the distribution of income on the one hand and its impact on growth and innovation on the other hand, are a rather neglected channel in the recent inequality-growth literature. ${ }^{14}$ It is an undisputed fact, however, that the income distribution affects the structure of demand. This is documented by one of the few robust empirical facts in economics: Engel's law which states that the expenditure share devoted to food is decreasing in the level of income. ${ }^{15}$ Very poor households have to concentrate most of their expenditure to basic goods and are no customers of innovative products. 


\section{Summary}

This paper started with a brief review of the empirical facts on trends in income distribution in the last century as well as in the more recent past. The data show significant changes in distributional trends in the more recent past for various countries, but no universal trend towards more inequality. In a next step I discussed the recent evidence concerning the empirical relationship between inequality and long-run growth. Interestingly, this evidence does not support the proposition that inequality is a necessary condition for a prosperous long-run development. If a relationship between inequality and growth exists at all, the empirical evidence shows that there is a negative relation between these two variables.

Economic research on the inequality-growth puzzle has concentrated on the role of the personal distribution. With few exceptions the functional distribution has received far less attention. This is not justified both from an empirical as well as from a theoretical point of view.

Explanations of a possible negative relationship between inequality and growth concentrate on politico-economic and sociological approaches, but in particular on the consequences of capital market imperfections. There is no doubt that liquidity constraints are an important channel by which negative effects of inequality are transmitted, both in developing countries as well as in industrialized countries.

Finally, I presented an approach which in my view is important but has so far been rather neglected in the literature: the role of expected demand for the incentives to innovate in an economy.

If one shares the opinion that distributional conflicts in modern economies will be not alleviated in the near future, one can expect that the question of how income and wealth inequality affects macroeconomic outcomes will be a subject of increasing importance. The explanatory power of the various approaches is, of course, an empirical question, and so far the literature is far from providing concluding answers. However, the most important prerequisite before conclusions for economic policy can be drawn is to clarify the crucial mechanisms by which inequality affects growth. Ultimately, it is not only important to know whether less inequality can increase growth, but also which policies should be adopted to eventually increase both equality and growth. 


\section{References}

Aghion, P. and P. Bolton. (1997). “A Trickle-Down Theory of Growth and Development with Debt-Overhang," Review of Economic Studies 64, 151-172.

Aghion, P. and P. Howitt. (1998). Endogenous Growth Theory. Cambridge, MA: MIT Press.

Aghion, P., Caroli E. and C. Garcia-Penalosa. (1999). "Inequality and Economic Growth: the Perspective of the New Growth Theories, Journal of Economic Literature, forthcoming.

Alesina, A., S. Özler, N.Roubini and P.Swagel. (1996). "Political Instability and Economic Growth," Journal of Economic Growth 1, 189-211.

Alesina, A. and D. Rodrik. (1994). "Distributive Politics and Economic Growth," Quarterly Journal of Economics 109, 465-490.

Anand, S. and R. Kanbur. (1993). "The Kuznets-Process and the Inequality-Development Relationship," Journal of Development Economics 40, 25-52.

Atkinson, A. (1997). "Bringing Income Distribution in from the Cold," Economic Journal 107, 297-321.

Atkinson, A. (1998). The Distribution of Income in Industrialized Countries. Income Inequality Issues and Policy Options Symposium Proceedings, Federal Reserve Bank of Kansas City.

Baland, J.-M. and D. Ray. (1991). "Why Does Asset Inequality Affect Unemployment? A study of the demand composition problem," Journal of Development Economics 35, 69-92.

Banerjee, A.V. and A. Newman. (1993). "Occupational Choice and the Process of Development," Journal of Political Economy 101, 274-298.

Barro, R.(1999). “Inequality, Growth and Investment,” NBER Working Paper \# 7038.

Benabou, R. (1996). “Inequality and Growth.” In B.S. Bernanke and J.J. Rotemberg (eds.), NBER Macroeconomics Annual 1996. Cambridge, MA: MIT Press.

Bentolila, S. and G. Saint-Paul. (1999). "Explaining Movements in the Labor Share," mimeo, Universitat Pompeu Fabra, Barcelona.

Berg A. and J. Sachs. (1988). "The Debt Crisis: Structural Explanations of Country Performance," Journal of Development Economics 29, 271-306.

Bertola, G. (1993). "Factor Shares and Savings in Endogenous Growth," American Economic Review 83, 1184-1198.

Bertola, G. (1996). "Factor Shares in OLG-Models of Growth," European Economic Review 40, 1541-1560.

Bertola, G. (1999). "Macroeconomics of Distribution and Growth.” In A. Atkinson and F. Bourguignon (eds.), Handbook of Income Distribution, forthcoming. Amsterdam: NorthHolland. 
Black, J., D.de Meza and d. Jeffreys. (1996). "House Prices, the Supply of Collateral and the Enterprice Economy," Economic Journal 106, 60-75.

Chou C.-F. and G. Talmain. (1996). "Redistribution and Growth: Pareto Improvements," Journal of Economic Growth 1, 505-523.

Clarke, R. (1995). “More Evidence on Income Distribution and Growth," Journal of Development Economics 47, 403-427.

Cole, H., G. Mailath, und A. Postlewaite. (1992). "Social Norms, Savings Behavior, and Growth“, Journal of Political Economy 100, 1092-1125.

Corneo, G. und 0. Jeanne. (1998). "Social Organization, Status, and Savings Behavior", Journal of Public Economics 70, 3 7-5 1.

Deaton, A. S. and J. Muellbauer. (1980). Economics and Consumer Behavior, Cambridge, MA: CUP.

Deininger, K. and L. Squire. (1998). "New Ways Looking at Old Issues: Inequality and Growth," Journal of Development Economics 57, 259-287.

Diamond, P.A. (1965). "National Debt in a Neoclassical Growth Model," American Economic Review 55, 1126-1150.

Eswaran, M. and A. Kotwal. (1993). “A Theory of Real Wage Growth in LDCs,” Journal of Development Economics 42, 243-269.

Falkinger, J. (1990). “On Growth along a Hierarchy of Wants,” Metroeconomica 41, 209-223.

Falkinger, J. (1994). “An Engelian Model of Growth and Innovation with Hierarchic Demand and Unequal Incomes," Ricerche Economiche 48, 123-139.

Falkinger, J. (1997). Wachstum, Verteilung und Beschäftigung, Working Paper 9712, Universität Linz.

Falkinger, J. and J. Zweimüller. (1996). “The Cross-country Engel-curve for Product Diversification," Structural Change and Economic Dynamics 7, 79-97.

Forbes, N. (1998). “A Reassessment of the Relationship between Inequality and Growth,” mimeo, MIT, 1998.

Galor, O. and J. Zeira. (1993). "Income Distribution and Macroeconomics," Review of Economic Studies 60, 35-52.

Glass, A. J. (1996). “Income Distribution and Quality Improvement,” mimeo, Ohio State University.

Jackson, L. F. (1984). "Hierarchic Demand the Engel-curve for Variety," Review of Economics and Statistics 66, 8-15.

Hall, R. and C. Jones. (1998). "Why Do Some Countries Produce So Much More Output Per Worker Than Others?", NBER Working Paper No. 6564. 
Kaldor, N. (1956). "Alternative Theories of Distribution", Review of Economic Studies 23, 83- 100.

Keefer, P. and S. Knack. (1995). „Polarisation, Property Rights and the Links Between Inequality and Growth“, World Bank,- Mimeo.

Knack, S. and P. Keefer. (1997). "Does Social Capital Have an Economic Payoff? A Cross Country Investigation", Quarterly Journal of Economics, 1251-1288.

Knell, M. (1999). "Social Comparisons, Inequality, and Growth,” Journal of Institutional and Theoretical Economics, forthcoming.

Kuznets, S.(1995). "Economic Growth and Income Inequality,” American Economic Review 45, 128.

Li, C.-W. (1996). "Inequality and Growth: a Schumpeterian Perspective," mimeo, University of Glasgow.

Li, H., Squire L. and H.-F. Zou. (1998). "Explaining International and Intertemporal Variations in Income Inequality," Economic Journal 108, 26-43.

Li, H. and H.-F. Zou. (1997). "Income Inequality is not Harmful for Growth: Theory and Evidence," mimeo, The World Bank.

Lindert, P.H. and J.G. Williamson. (1985). "Inequality, Growth and History," Explorations in Economic History 22, 341-377.

Murphy, K.M., A. Shleifer, and R. Vishny. (1989a). "Income Distribution, Market Size, and Industrialization," Quarterly Journal of Economics 104, 537-564.

Perotti, R. (1996). “Growth, Income Distribution and Democracy: What the Data Say," Journal of Economic Growth 1, 149-187.

Persson, T. and G.Tabellini. (1994). "Is Inequality Harmful for Growth?," American Economic Review 84, 600-621.

Poterba, J. (1997). “The Rate of Return to Corporate Capital and Factor Shares: New Estimates Using Revised National Income Accounts and Capital Stock Data,” NBER Working Paper \# 6263.

Rosenzweig M.R. and K.I.Wolpin. (1993). “Credit Market Constraints, Consumption Smoothing, and the Accumulation of Durable Production Assets in Low-Income Countries: Investment in Bullocks in India," Journal of Political Economy 101, 223-244.

Uhlig, H. and N. Yanagawa. (1996). "Increasing the Capital Income Tax May Lead to Faster Growth," European Economic Review 40, 1521-1540.

Zweimüller, J. and J.K. Brunner. (1998). "Innovation and Growth with Rich and Poor Consumers," CEPR Discussion Paper No. 1855, London.

Zweimüller, J. (1999). "Schumpeterian Entrepreneurs Meet Engel's Law: the Impact of Inequality on Innovation-Driven Growth," CEPR Discussion Paper No. 1880, revised version. 
*) Keynote-speech, Annual Meeting of the Austrian Economic Association, Linz 1999. I am indebted to Josef Falkinger for critical comments on a previous version of this paper and for numerous discussions on the subject. I am also grateful to Armin Falk, Simon Gächter, Markus Knell, and Martin Brown and to participants of the Austrian Economic Association Meeting at Linz for comments.

${ }^{1}$ For more comprehensive reviews of the recent literature on the interrelationship between income inequality and economic growth, see e.g. Benabou (1996), Aghion and Howitt (1998), Bertola (1999), and Aghion, Caroli and GarciaPenalosa (1999). For a broader discussion of the role of inequality, see e.g. Atkinson (1997) and Falkinger (1997).

${ }^{2}$ For recent empirical work on the Kuznets hypothesis see Anand and Kanbur (1993), Deininger and Squire (1998) and Barro (1999).

${ }^{3}$ For a recent paper dealing with the evolution of income inequality in a cross-section of countries, see Li, Squire and Zou (1998).

${ }^{4}$ Figure 3 is based on OECD-data. For similar evidence see Poterba (1997).

${ }^{5}$ The variables on the axes are residuals from a regression of the long-run growth rates and the Gini-coefficients, respectively, on exogenous variables. The measures for these variables are therefore conditional on country-specific factors. See Clarke (1995).

${ }^{6}$ The empirical debate about the inequality-growth relationship is ongoing. One issue is the periodicity of the growth period, another is whether the relationship is different between rich and poor economies. Perotti (1996) provides evidence that the inequality-growth relationship is negative and significant for rich but not for poor countries focusing on 30 year period. Using pooled cross-country data Barro (1999) finds the opposite. Regressing 10-years growth rates on inequality indicators yields a negative and significant coefficient for the poor economies but positive and significant estimate for the rich countries. Li and Zou (1997) focusing on 5-year periods and Forbes (1998) on yearly growth rates find a robust negative relationship in a sample of rich and poor countries

${ }^{7}$ The analysis in this section draws on the papers by Uhlig and Yanagawa (1996) and Bertola (1996).

${ }^{8}$ See Perotti (1996) for a test of the 'fiscal policy' approach.

${ }^{9}$ E.g. Alesina et al (1996) and Perotti (1996) provide evidence on these issues.

${ }^{10}$ Among many others, see Hall and Jones (1998), Keefer and Knack (1995), Knack and Keefer (1997) for recent empirical papers. For theoretical studies on the subject see Cole et al. (1992), Corneo and Jeanne (1998) and Knell (1999).

${ }^{11}$ Among the most important papers are Galor and Zeira (1993), Banerjee and Newman (1993), Benabou (1996), and Aghion and Bolton (1997).

${ }^{12}$ Empirical literature on the impact of credit-constraints based on micro-evidence is scarce. Among the few papers are Rosenzweig and Wolpin (1993) and Black et al. (1996).

${ }^{13}$ This model focuses on demand effects, but leaves the possibility that income inequality has an impact on the prices that can be charged by monopolistic producers out of consideration. For models where inequality has an impact on the incentive to innovation via prices see Li (1998), Glass (1998) and Zweimüller and Brunner (1998).

${ }^{14}$ Exceptions are Falkinger $(1990,1994)$ and Chou and Talmain (1996). For papers that focus on demand composition in static models see Murhpy, Shleifer and Vishny (1989), Eswaran and Kotwal (1993).

${ }^{15}$ There is ample evidence for Engel's law. See for instance Deaton and Mullbauer (1980). Jackson (1984) shows evidence for an Engel curve for product diversity using micro-level consumption data. Falkinger and Zweimüller (1996) provide evidence from cross-country consumption data. 
Figure 1: The Kuznets Curve

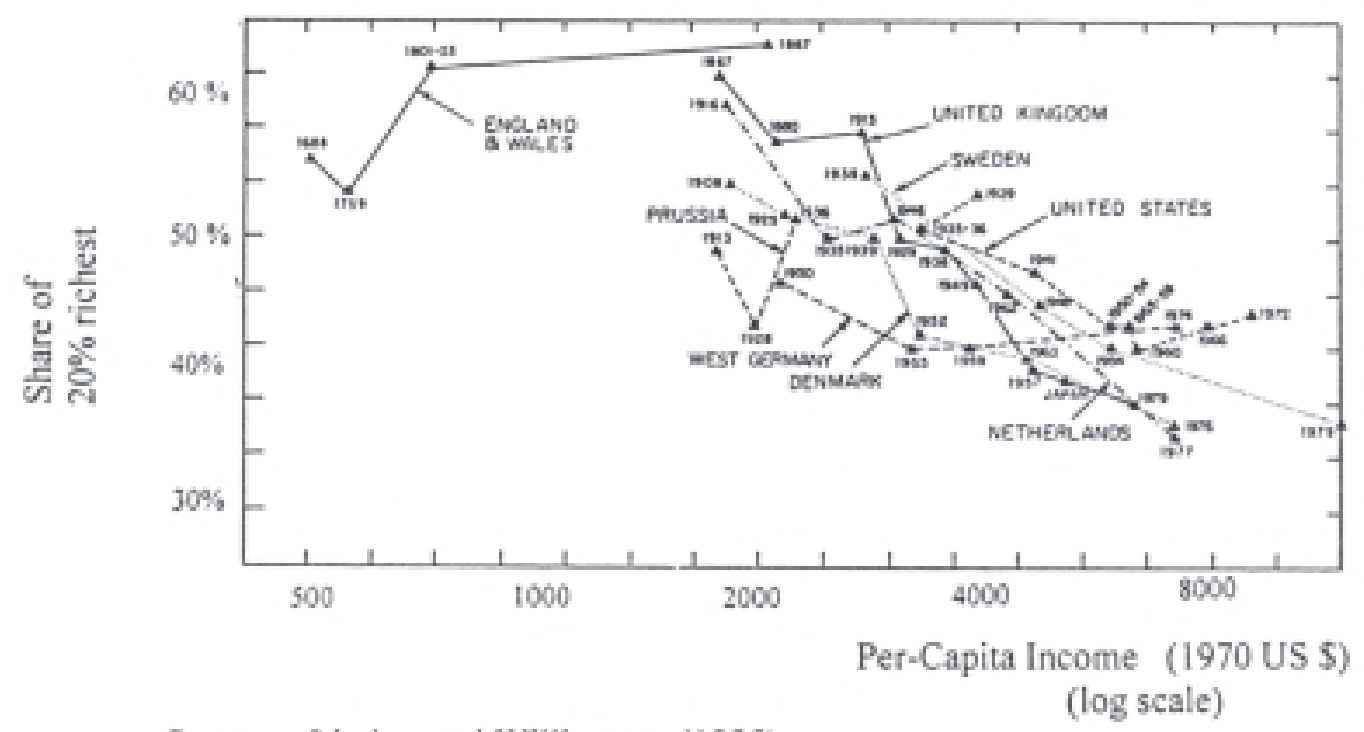

Source: Lindert and Williamson (1985) 
Figure 2: Recent Trends in Income Inequality

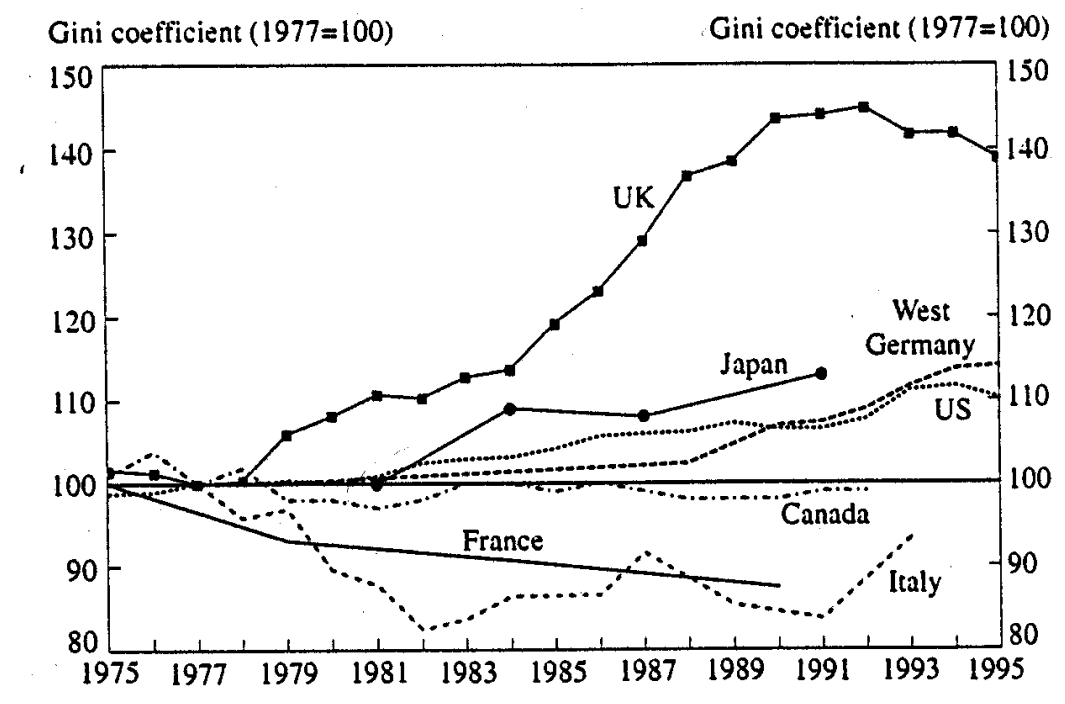

Source: Atkinson (1998) 
Figure 3: Changes in the Functional Distribution of Income

Labor share (percentage In GDP)
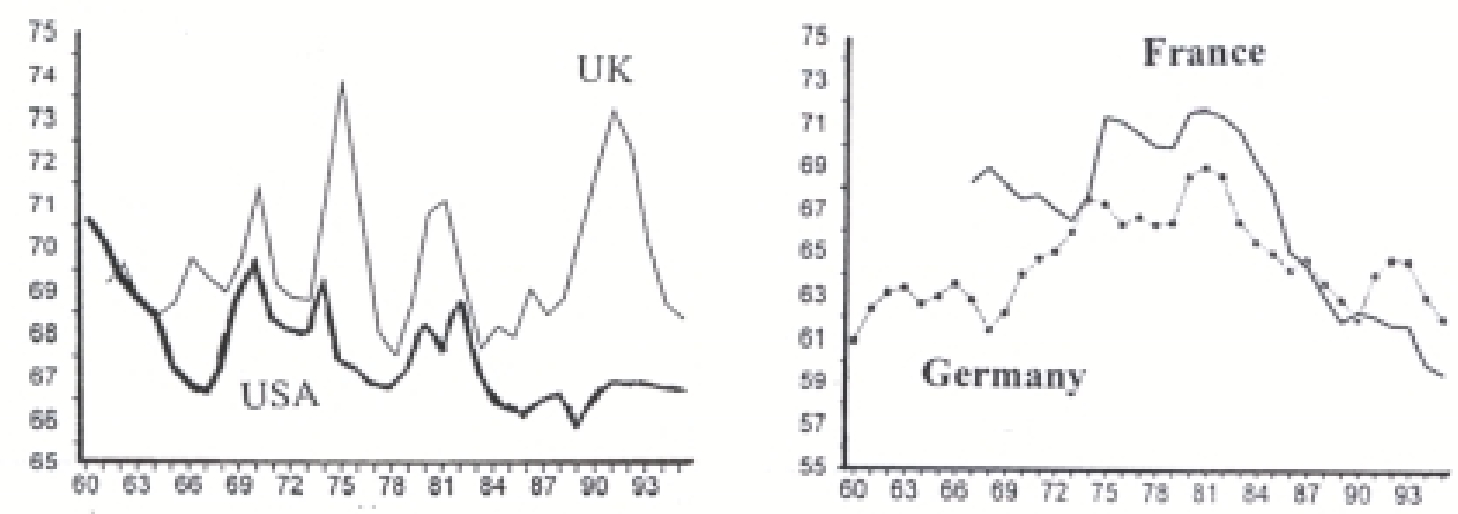

Source: Bentolia and Saint-Paul (1999) 
Figure 4: Inequality and Growth

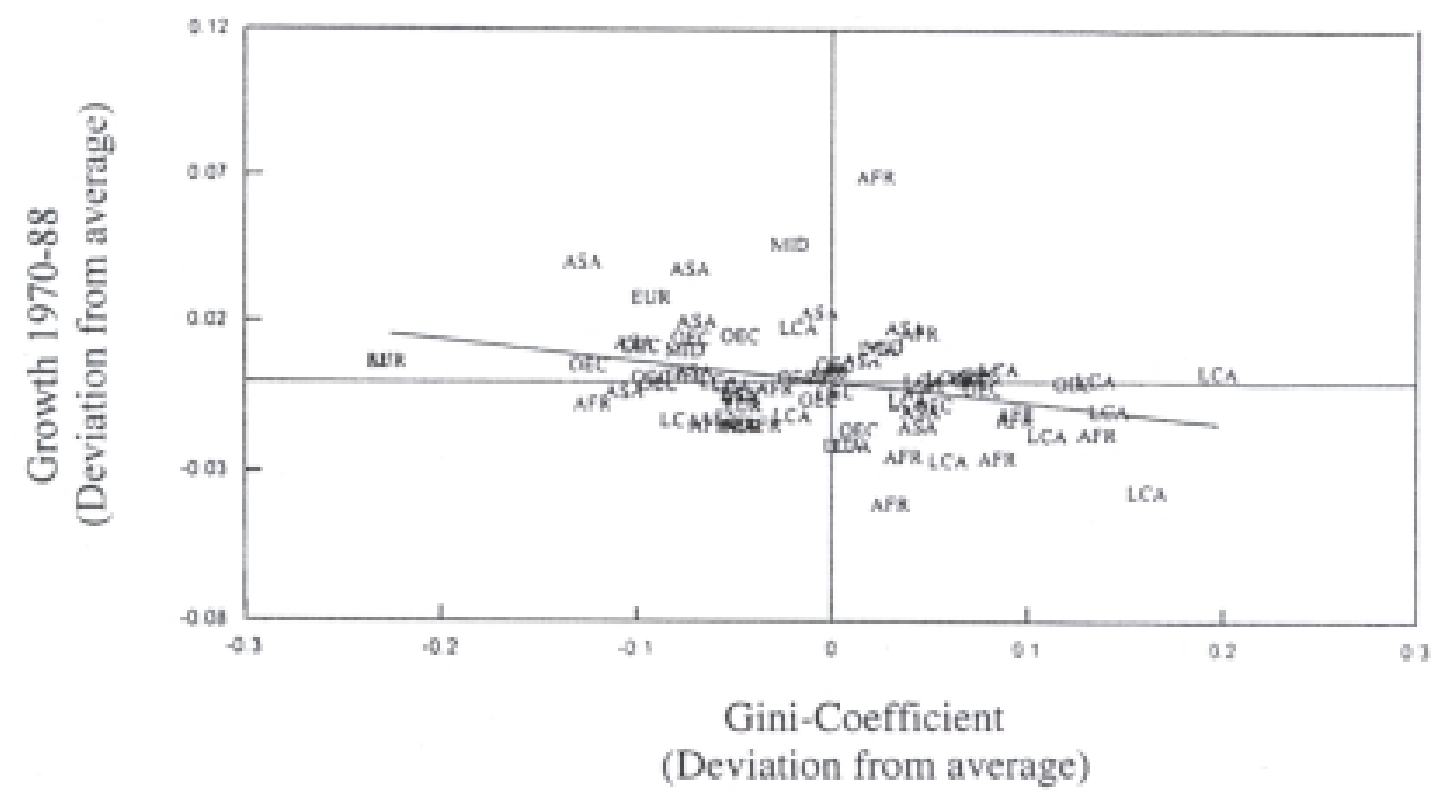

Source: Clarke (1995) 
Figure 5: Capital Texation and Aggregate Savings, U.S. 1965 - 1990

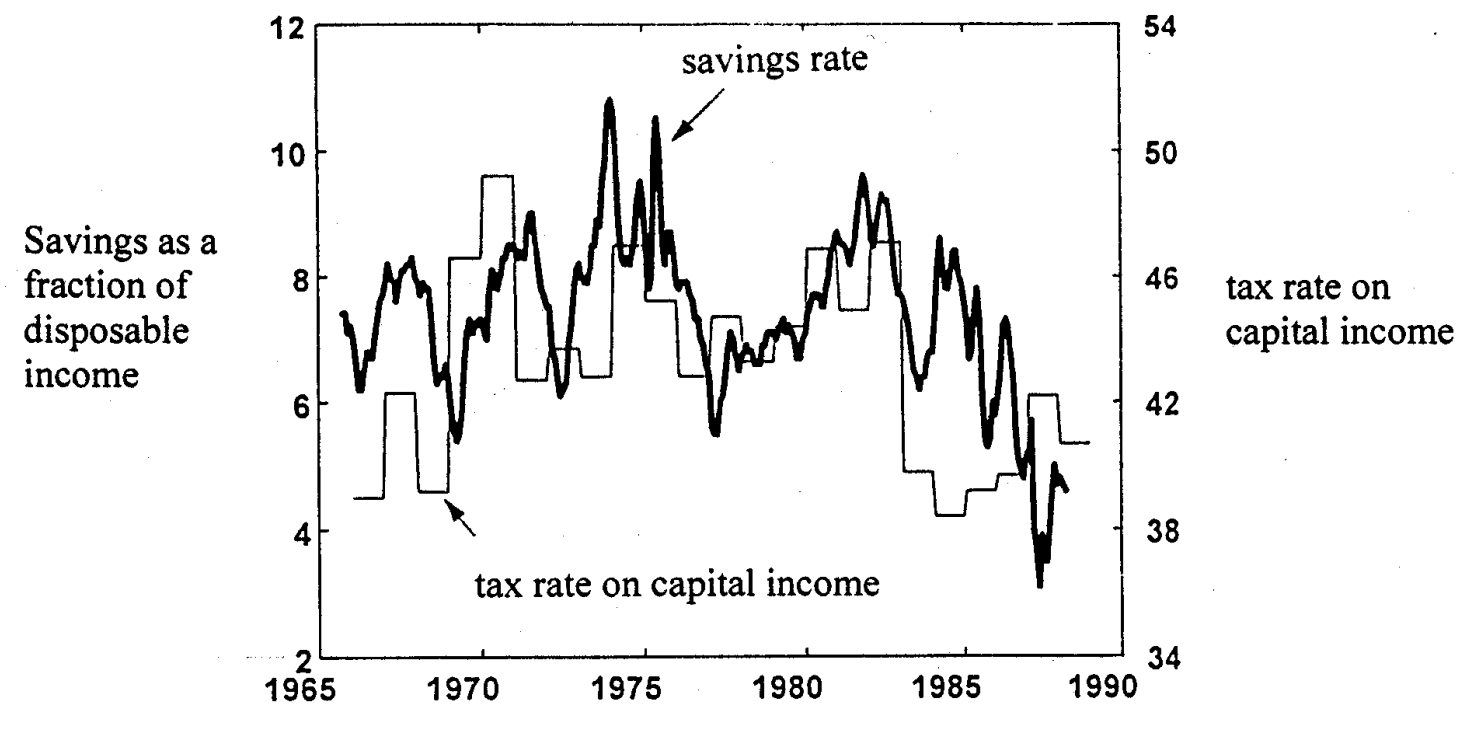

Source: Uhlig and Yanagawa (1996) 
Figure 6: Investment in Human Capital

With Perfect Capital Markets

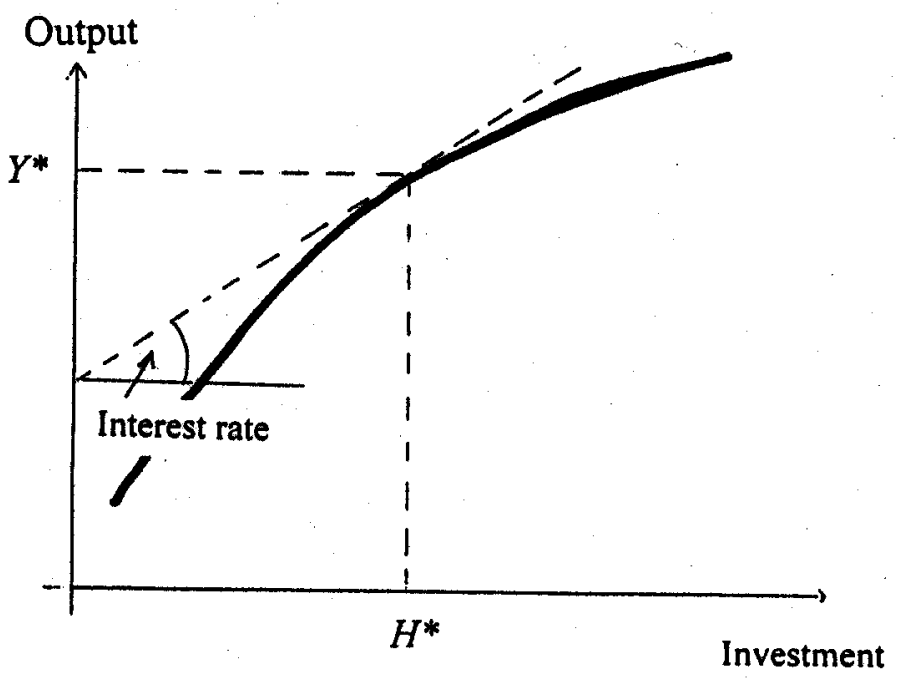


Figure 7: Imperfect Capital Markets

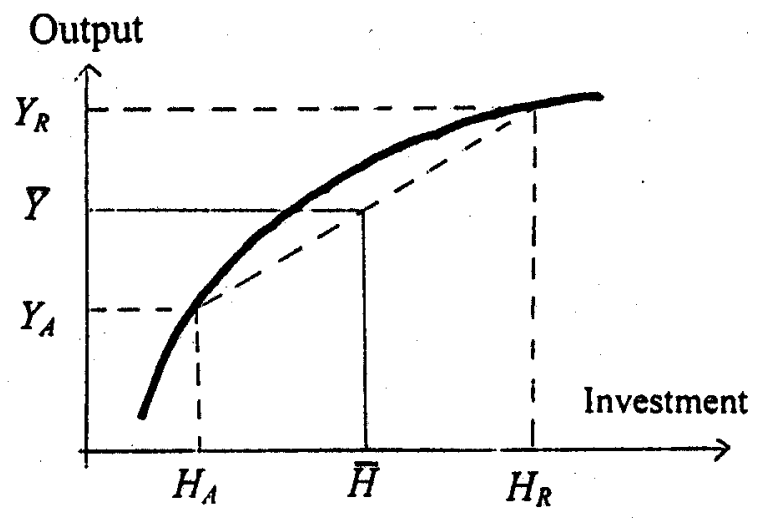


Figure 8: Income Inequaltity and the Dynamics of Demand

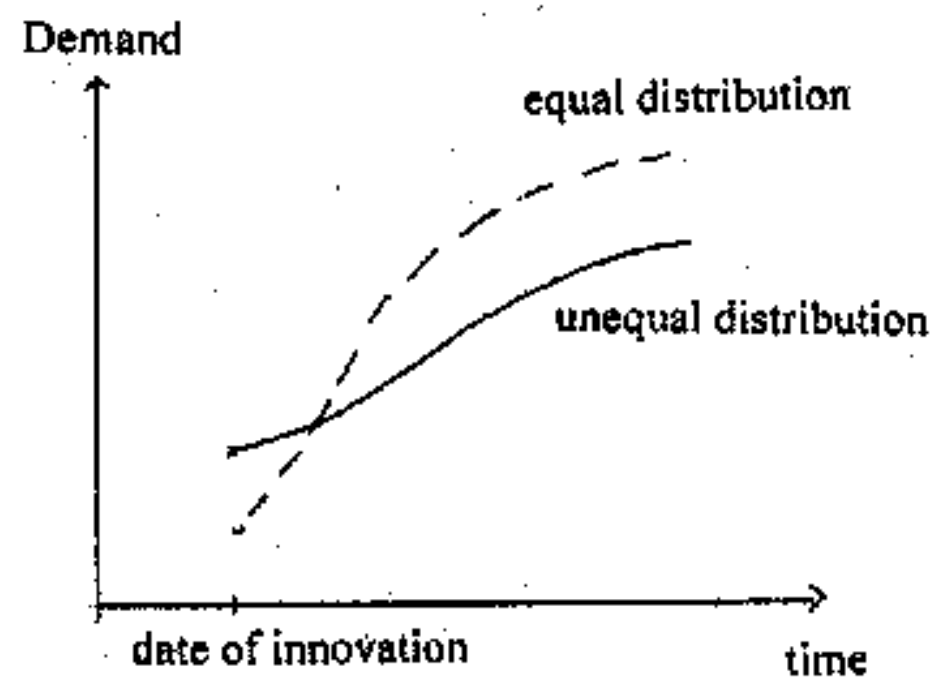


Figure 9: Income Distribution and The Composition of Demand

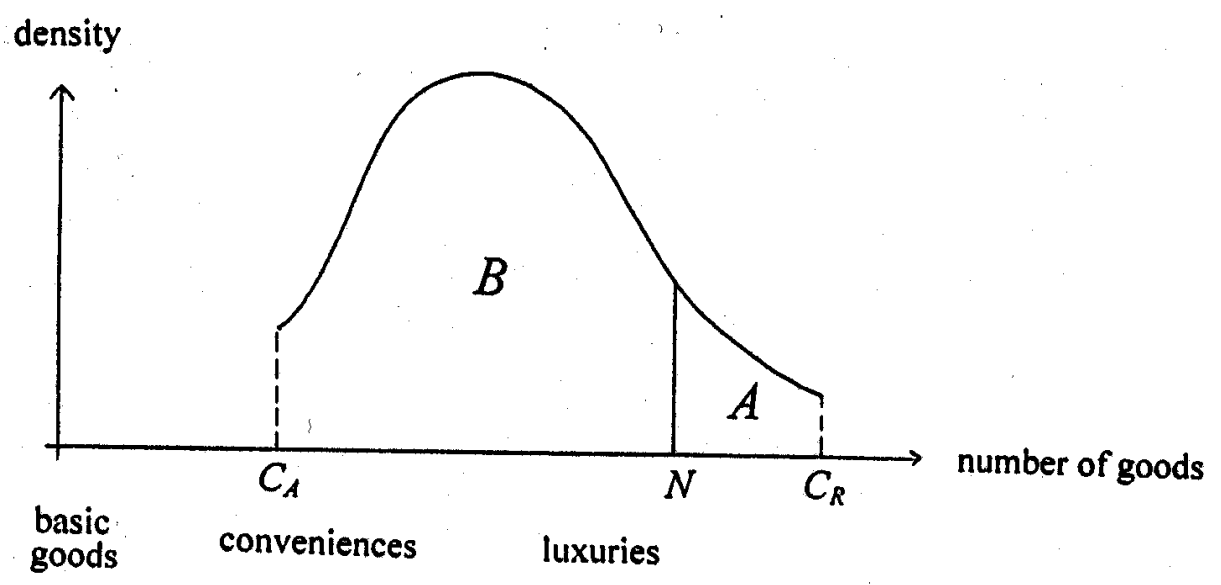




\section{Working Papers of the Institute for Empirical Research in Economics}

No.

1. Rudolf Winter-Ebmer and Josef Zweimüller: Firm Size Wage Differentials in Switzerland: Evidence from Job Changers, February 1999

2. Bruno S. Frey and Marcel Kucher: History as Reflected in Capital Markets: The Case of World War II, February 1999

3. Josef Falkinger, Ernst Fehr, Simon Gächter and Rudolf Winter-Ebmer: A Simple Mechanism for the Efficient Provision of Public Goods - Experimental Evidence, February 1999

4. Ernst Fehr and Klaus M. Schmidt: A Theory of Fairness, Competition and Cooperation, April 1999

5. Markus Knell: Social Comparisons, Inequality, and Growth, April 1999

6. Armin Falk and Urs Fischbacher: A Theory of Reciprocity, April 1999

7. Bruno S. Frey and Lorenz Goette: Does Pay Motivate Volunteers?, May 1999

8. Rudolf Winter-Ebmer and Josef Zweimüller: Intra-firm Wage Dispersion and Firm Performance, May 1999

9. Josef Zweimüller: Schumpeterian Entrepreneurs Meet Engel's Law: The Impact of Inequality on InnovationDriven Growth, May 1999

10. Ernst Fehr and Simon Gächter: Cooperation and Punishment in Public Goods Experiments, June 1999

11. Rudolf Winter-Ebmer and Josef Zweimüller: Do Immigrants Displace Young Native Workers: The Austrian Experience, June 1999

12. Ernst Fehr and Jean-Robert Tyran: Does Money Illusion Matter?, June 1999

13. Stefan Felder and Reto Schleiniger: Environmental Tax Reform: Efficiency and Political Feasibility, July 1999

14. Bruno S. Frey: Art Fakes - What Fakes?, An Economic View, July 1999

15. Bruno S. Frey and Alois Stutzer: Happiness, Economy and Institutions, July 1999

16. Urs Fischbacher, Simon Gächter and Ernst Fehr: Anomalous Behavior in Public Goods Experiments: How Much and Why?: Comment, August 1999

17. Armin Falk, Ernst Fehr and Urs Fischbacher: On the Nature of Fair Behavior, August 1999

18. Vital Anderhub, Simon Gächter and Manfred Königstein: Efficient Contracting and Fair Play in a Simple Principal-Agent Experiment, August 1999

19. Simon Gächter and Armin Falk: Reputation or Reciprocity?, September 1999

20. Ernst Fehr and Klaus M. Schmidt: Fairness, Incentives, and Contractual Choices, September 1999

21. Urs Fischbacher: z-Tree - Experimenter's Manual, September 1999

22. Bruno S. Frey and Alois Stutzer: Maximising Happiness?, October 1999

23. Alois Stutzer: Demokratieindizes für die Kantone der Schweiz, October 1999

24. Bruno S. Frey: Was bewirkt die Volkswirtschaftslehre?, October 1999

25. Bruno S. Frey, Marcel Kucher and Alois Stutzer: Outcome, Process \& Power in Direct Democracy, November 1999

26. Bruno S. Frey and Reto Jegen: Motivation Crowding Theory: A Survey of Empirical Evidence, November 1999

27. Margit Osterloh and Bruno S. Frey: Motivation, Knowledge Transfer, and Organizational Forms, November 1999

28. Bruno S. Frey and Marcel Kucher: Managerial Power and Compensation, December 1999

29. Reto Schleiniger: Ecological Tax Reform with Exemptions for the Export Sector in a two Sector two Factor Model, December 1999

30. Jens-Ulrich Peter and Klaus Reiner Schenk-Hoppé: Business Cycle Phenomena in Overlapping Generations Economies with Stochastic Production, December 1999

31. Josef Zweimüller: Inequality, Redistribution, and Economic Growth, January 2000

The Working Papers of the Institute for Empirical Research in Economics can be downloaded in PDF-format from http://www.unizh.ch/iew/wp/

Institute for Empirical Research in Economics, Blümlisalpstr. 10, 8006 Zürich, Switzerland

Phone: 004116343705 Fax: 004116344907 E-mail: bibiewzh@iew.unizh.ch 